\title{
New Record of Ephemeroporus tridentatus Bergamin, 1939 (Crustacea; Anomopoda; Chydoridae) from Colombia
}

\author{
Barón-Rodríguez, MM. ${ }^{\mathrm{a} *}$ and Gavilán-Díaz, $R A .^{\mathrm{b}}$ \\ ${ }^{a}$ Grupo de Estudios en Biodiversidad, Universidad Industrial de Santander, Santander, Colombia \\ 'Laboratorio de Limnología, Grupo de Estudios en Biodiversidad, Escuela de Biología, \\ Universidad Industrial de Santander, Santander, Colombia \\ *e-mail: mmercedes30@yahoo.com \\ Received November 9, 2005 - Accepted February 1, 2006 - Distributed May 31, 2007
}

(With 1 figure)

The presence of Ephemeroporus tridentatus (Bergamin, 1939), considered as belonging to Chydorus poppei or C. barroisi in previous studies (Elmoor-Loureiro, 1997), has been reported in South America: in Venezuela (Orinoco basin) (Zoppi de Roa et al., 1985; Rey and Vásquez, 1988) and in Brazil (Smirnov, 1996; Elmoor-Loureiro 1997; 1998), where it has been restored as a valid and highly distinctive species. The present study constitutes the first record of $E$. tridentatus in Colombia.

"Ciénaga de Paredes" (Paredes Marsh), where E. tridentatus was found, is located halfway along the course of the "Río Magdalena" (Magdalena River) in the municipalities of Puerto Wilches and Sabana de Torres (Department of Santander, Colombia, South America, $73^{\circ} 45^{\prime}-73^{\circ} 49^{\prime} \mathrm{W}$ and $7^{\circ} 26^{\prime}-7^{\circ} 29^{\prime} \mathrm{N}, 75 \mathrm{~m}$. of altitude). The samples analyzed in this study were obtained from eight sites during 11 field trips, which were carried out between February 1998 and January 1999. The Cladocera were collected throughout the entire water column, using a plankton net ( $68 \mu \mathrm{m}$ mesh). The samples were fixed with formalin $4 \%$ and glucose $8 \%$. The analyzed biological samples belong to the limnological collection of the Museo de Historia Natural (Museum of Natural History) of the Universidad Industrial de Santander. Their inventory numbers are UIS ML 0013 to UIS ML 0187.

The environmental conditions were the following: precipitation $204 \mathrm{~mm}$ (biomodal regime, dry season), water temperature $32.7^{\circ} \mathrm{C}$, conductivity $13.33 \mu \mathrm{S} . \mathrm{cm}^{-1}$, turbidity $97.83 \mathrm{NTU}$, OD $7.73 \mathrm{mg} . \mathrm{L}^{-1}$, transparency $0.23 \mathrm{~m}$ and $\mathrm{pH} 6.96$.

On average, the number of specimens found per cubic meter was, temporally, 91 ind. $\mathrm{m}^{-3}$ and, spatially, 126 ind. $\mathrm{m}^{-3}$. The greatest number of organisms was recorded in the sample that was obtained in March, at a point near the mouth of "Quebrada El Champán" (El Champán Stream), 275 ind. $^{-3}$. The abundance of E. tridentatus revealed a positive correlation with conductivity, turbidity, numeric density, and Cladocera richness $(r=0.3437$, $\mathrm{p}=0.001, \mathrm{r}=0.4881, \mathrm{p}=0.000, \mathrm{r}=0.2145, \mathrm{p}=0.045$ and $r=0.2134, p=0.046$, respectively), and a negative correlation with depth, and transparency $(r=-0.2702$, $\mathrm{p}=0.011$ and $\mathrm{r}=-0.2843, \mathrm{p}=0.007$, respectively).

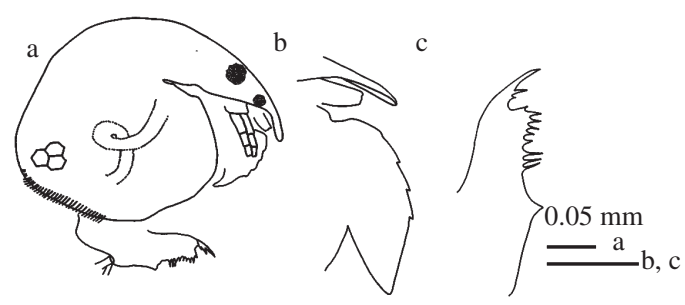

Figure 1. Ephemeroporus tridentatus. a) adult parthenogenetic female; b) labral plate; and c) postabdomen.

The observed specimens of E. tridentatus have the following length: medium $0.25 \mathrm{~mm}$, maximum $0.3 \mathrm{~mm}$, and minimum $0.19 \mathrm{~mm}$. These variables correspond to those found by Smirnov (1996) and Elmoor-Loureiro (1997). The studied specimens of E. tridentatus presented the following morphological characteristics: short rostrum tapered to a finely rounded tip; ocellus smaller than eye; ventral margin of valve with row of setae in the posterior half situated on the inner side; valve with pattern of polygons without denticles at posterior angle of valve but with several (2-3) spine-like setae (Figure 1a); 3-4 teeth on the labral plate (Figure 1b); antennae with setae 0-1-3/0-0-3; claw with two basal spines; postabdomen with the postanal part sub-square and marginal teeth of growing size on both sides (Figure 1c); and the diagnostic characteristics previously outlined by ElmoorLoureiro (1997) and Smirnov (1974; 1996).

Based on the aforementioned morphological characteristics and distribution, we may conclude that the specimens found at "Ciénaga de Paredes" belong to $E$. tridentatus. As we stated before, this is the first record of E. tridentatus in Colombia.

Acknowledgments - We thank Dra. Evelyn Zoppi de Roa (Universidad Central de Venezuela) and Dra. Marina Manca (Istituto per lo Studio degli Ecosistemi - CNR), for their help in species determination.

\section{References}

FREY, DG., 1982. Relocation of Chydorus barroisi and related species (Cladocera: Chydoridae) to a new genus and description 
of two new species zooplankton. Hydrobiologia, vol. 86, no. 3 , p. 231-269.

ELMOOR-LOUREIRO, LMA., 1997. Manual de identifição de Cladóceros límnicos do Brasil. Editora Universa. Universidade Católica de Brasília, Brasil. 155p.

-, 1998. Branchiopoda. Freshwater Cladocera, p. 15-41. In YOUNG PS. (ed.). Catalogue of Crustacea of Brazil. Rio de Janeiro: Museu Nacional. (Série Livros no. 6).

REY, J. and VÁSQUEZ, E., 1988. Notas sobre los avances de las investigaciones de los cladóceros (Crustacea, Cladocera) de la Cuenca Baja del Orinoco. Sociedad de Ciencias Naturales La Salle XLVIII, vol. 48, no. 129, p. 155-161.
SMIRNOV, NN., 1974. Chydoridae of the world's fauna. Fauna of the USSR - Crustacea, vol. 1, no. 2, p. 1-644.

-, 1996. Cladocera: The Chydorinae and Sayciinae (Chydoridae) of the World. Guides to the Identification of the Microinvertebrates of the Continental Waters of the World vol. 11, p. 1-197. SPB Academic publishing, The Netherlands. $197 \mathrm{p}$.

ZOPPI DE ROA, F., MICHELANGELLI, F. and SEGOVIA, L., 1985. Cladocera (Crustacea, Branchiopoda) de sabanas inundables de Mantecal, Estado Apure, Venezuela. Acta Biol. Venez., vol. 12, p. 43-55. 